\section{Aula de campo em Geomorfologia: entre Santa Maria e São Martinho da Serra, RS}

\begin{abstract}
Resumo: O presente trabalho descreve algumas características geomorfológicas de lugares em quatro pontos de paradas no percurso desenvolvido em aula de campo desde Santa Maria, RS até São Martinho da Serra, RS. Foram observados o comportamento do relevo face ao controle estrutural, litológico e a dinâmica erosiva que atua nos processos de modelado do relevo. A metodologia seguiu a abordagem dedutiva, partindo de conceitos teóricos trabalhados em sala de aula. $\mathrm{Na}$ análise do relevo foram consideradas abordagens descritivas a partir de modelos estático e dinâmico, visando compreender a relação dos processos morfogenéticos a partir da estrutura e da dinâmica erosiva, além de estabelecer a relação entre o modelado do relevo, o perfil e forma das vertentes, o comportamento do manto pedológico na conformação geral da paisagem. No percurso realizado, observaram-se relevos desenvolvidos sobre sedimentos atuais e terraços fluviais, bem como relevos desenvolvidos sobre litologias da Formação Santa Maria (Membro Alemoa), Caturrita, Botucatu e Serra Geral. Também foram reconhecidos contatos litológicos entre as Formações Caturrita e Botucatu e, entre as Formações Botucatu e Serra Geral.
\end{abstract}

\section{Field class in Geomorphology: between Santa Maria and São Martinho da Serra, RS}

\begin{abstract}
This paper describes some geomorphological characteristics of places at four points of stops on the route developed in field class from Santa Maria, RS, Brazil to São Martinho da Serra, RS both the cities located in state of Rio Grande do Sul, Brazil. During the course were performed four stops for the purporse of observing the relief's behavior compared to the structural-lithologic control and the erosive dynamic that acts in the modeled in relief processes. The methodology followed the deductive approach, using theoretical concepts worked in the classroom. Thus, we considered a static approach and other dynamics to the evolution of relief, seeking to understand the relationship of morphogenetic processes from the structure and erosive dynamics establishing the relationship between the modeled relief, the hogback profile and shape of the slopes, pedological mantle behavior in general conformation of the landscape. On the route taken, there were observed developed reliefs over current sediments and current river terraces as well as relieves well developed over the lithologies of Santa Maria Formation (Alemoa Member), Caturrita, Botucatu and Serra Geral. Was also visualized lithologic contacts between the Caturrita and Botucatu Formations and between the Botucatu and Serra Geral Formations.
\end{abstract}

\author{
Mauro Kumpfer \\ Werlang* \\ Rodrigo Correa \\ Pontes** \\ Francieli Lima \\ Sarmento**
}

* Professor do Departamento de Geociências da Universidade Federal de Santa Maria - UFSM.

** Discentes do curso de Bacharelado em Geografia da UFSM.

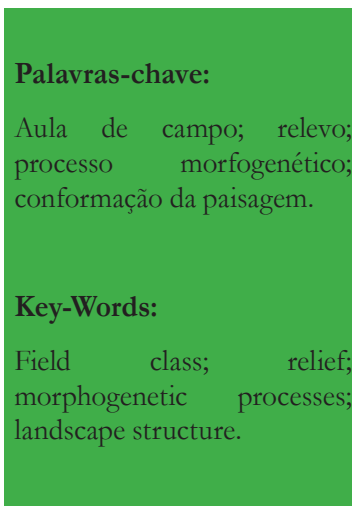




\section{Introdução}

No dia 13 de junho de 2012, os alunos da disciplina Geomorfologia B do Curso de GeografiaBacharelado da Universidade Federal de Santa Maria-UFSM, acompanhados pelo professor da disciplina, partiram para uma aula de campo, tendo como roteiro Santa Maria (Campus da UFSM) até São Martinho da Serra, RS. A aula teve como objetivo observar o comportamento do relevo face ao controle estrutural, litológico e a dinâmica erosiva que atua nos processos de modelado do relevo e reforçar alguns dos conceitos trabalhados em sala de aula. Visando compreender a relação dos processos morfogenéticos a partir da estrutura e da dinâmica erosiva, além de estabelecer a relação entre o modelado do relevo, o perfil e forma das vertentes, o comportamento do manto pedológico na conformação geral da paisagem, foram consideradas abordagens descritivas a partir de modelo estático e dinâmico para a evolução do relevo.

O roteiro de campo incluiu parte do município de Santa Maria, RS e de São Martinho da Serra, RS. O trajeto é marcado pela transição entre duas unidades morfestruturais. O município de Santa Maria, RS está localizado na Depressão Periférica Sul-riograndense, na região central do estado do Rio Grande do Sul. No Rebordo do Planalto (Planaltos e Chapadas da Bacia Sedimentar do Paraná) está localizado o município de São Martinho da Serra, RS. A Figura 1 localiza os municípios de São Martinho da Serra e Santa Maria em relação às províncias geomorfológicas do Rio Grande do Sul.

Buscou-se descrever as formas características de relevo em cada ponto de parada realizada no trajeto. Foram realizadas quatro paradas, nas quais se procurou observar o comportamento do relevo face ao controle estrutural, litológico e a dinâmica erosiva.

Durante o percurso realizado, observaram-se relevos assentados em sedimentos atuais e terraços fluviais, além de contatos litológicos entre a Formação Caturrita e Formação Botucatu e, entre a Formação Botucatu e Formação Serra Geral. Conforme Bortoluzzi (1974), o Membro Alemoa da Formação Santa Maria caracteriza-se por ser constituído de rochas sedimentares de textura maciça (sem orientação) de caráter argiloso a síltico (lamito com pequena ocorrência de concreções calcárias). Para a Formação Caturrita, tanto Bortoluzzi (1974), como Maciel Filho et al (1990) destacam que ela está constituída por camadas de arenitos finos a médios, de cor cinza claro de composição quartzosa. Com relação a formação Botucatu Bortoluzzi (1974) observa que essa Formação é composta por arenitos essencialmente quartzosos contendo feldspatos alterados, cimentados por sílica, predominantemente, ou por óxido de ferro. A Formação Serra Geral, de acordo com Veiga (1973), é constituída por duas seqüências vulcânicas: uma de caráter básico e outra ácida, com intercalação de sedimentação eólica, nos períodos de recesso da atividade vulcânica, conhecidos como arenitos "intertrapps”. Os depósitos Quaternários, pelo fato de serem originários da dinâmica presente e pré-atual de acumulação sedimentar, encontram-se associados aos atuais agentes de sedimentação e, ao buscar-se compreender as relações entre o manto pedológico e o relevo é preciso superar idéias preconcebidas como a que diz haver uma oposição entre os processos pedogenéticos (alteração das rochas, formação dos solos) e morfogenéticos (erosão, esculturação/esculpimento das formas de relevo). Esses processos podem ser simultâneos e, mais que isso, pode agir concomitantemente e, nesse sentido Werlang (2004), considera que as formas ou conjuntos de formas de relevo participam da composição das paisagens em diferentes escalas. Destaca que o relevo ao ser observado num curto espaço de tempo mostra aparência estática, entretanto, está sendo permanentemente

Geografia Ensino \& Pesquisa, v. 17, n.3, p. $229-241$, set./dez. 2013

Aula de campo em Geomorfologia: entre Santa Maria e São Martinho da Serra, RS trabalhado por processos erosivos ou deposicionais resultantes das condições climáticas existentes. Observa também que apesar do consenso em considerar que o modelado terrestre evolui, surgem questões de como e de que maneira se processa o desenvolvimento das formas de relevo; quais as condições iniciais e até que fase se processa a evolução. Conclui que muitas respostas estão no campo das teorias geomorfológicas uma vez que elas procuram orientar a observação na busca da explicação. 
Figura 1 - Localização dos municípios de São Martinho da Serra e Santa Maria em relação às províncias geomorfológicas do Rio Grande do Sul.

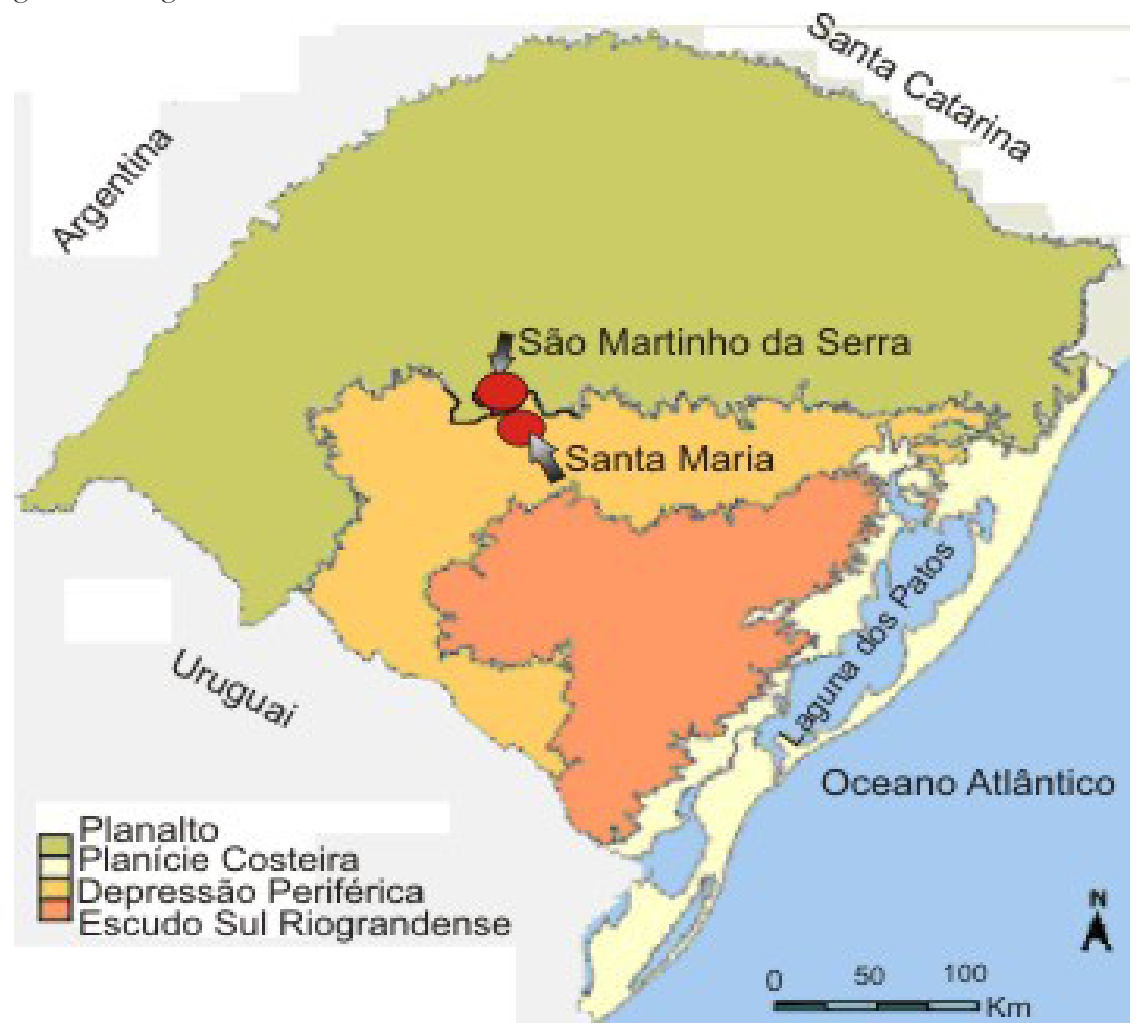

Fonte: adaptado de IBGE (2010).

Assim, no contexto da observação, considera-se que o trabalho de campo, na forma de aula, assume significativa importância para essas observações e possíveis explicações. Nesse sentido, na aula de campo, se buscou observar o comportamento do relevo a partir de alguns dos conceitos trabalhados em sala, considerando uma abordagem dedutiva que está baseada em hipóteses e experimentos/deduções. Buscou-se descrever as formas de relevo características observadas nos pontos de paradas realizadas no trajeto, face ao controle estrutural, litológico e a dinâmica erosiva das vertentes na conformação geral da paisagem.

\section{Metodologia}

O trabalho, desenvolvido como aula de campo, teve como abordagem metodológica a concepção do método dedutivo que está baseado em hipóteses e experimentos/deduções. Sobre isso Alves (1981) afirma que na dedução adota-se um conhecimento geral, uma afirmação válida que pode ser demonstrada ao examinarmos o objeto de estudo a partir de determinada lei geral.

Quando classificados em grupos epistemológicos os métodos podem ser indutivos, dedutivos, hipotético-dedutivo, dialético e fenomenológico. Para realização desta aula de campo, fez-se uso do método dedutivo, acreditando-se ser esta uma das formas que permite uma maior proximidade da realidade com a pesquisa e o ensino. Proposto por Popper, consiste na adoção da seguinte linha de raciocínio, conforme Gil (1999, p.30):

[...] quando os conhecimentos disponíveis sobre determinado assunto são insuficientes para a explicação de um fenômeno, surge o problema. Para tentar explicar as dificuldades expressas no problema, são formuladas conjecturas ou hipóteses. Das hipóteses formuladas, deduzem-se conseqüências que deverão ser testadas ou falseadas. Falsear significa tornar falsas as conseqüências deduzidas das hipóteses. Enquanto no método dedutivo se procura confirmar a hipótese, no método hipótetico-dedutivo procuram-se evidências empíricas para derrubá-la.

Geografia Ensino \& Pesquisa, v. 17, n.3, p. 229-241, set./dez. 2013

Werlang, M. K.; Pontes, R. C.; Sarmento, F. L. 
A partir de um roteiro percorreu-se o trajeto, fazendo-se paradas em pontos prédeterminados, onde se observou o comportamento do relevo, conforme os objetivos definidos para a aula de campo.

\section{Descrição dos pontos de paradas observados no percurso}

\section{Ponto de parada 1}

No primeiro ponto de parada foi observado o processo de ocupação urbana do setor noroeste de Santa Maria. Por se tratar de uma área de transição de ocupação urbana para a rural, aparecem características tanto de ocupação urbana como rural. Nessa área ocorrem litologias da Formação Santa Maria (Membro Alemoa). Foram observadas vertentes, com perfil e forma suavemente convexa e uma topografia suave ondulada. O modelado do relevo apresenta forma de dissecação fraca. Em alguns pontos formam-se coxilhas alongadas, apresentando-se na forma de pequenas encostas rampeadas, onde ocorrem fenômenos de erosão a partir a ação de canais incisivos. A Figura 2 ilustra a conformação predominante do relevo. Quanto a cobertura pedológica, predominam argissolos.

Figura 2 - Conformação do relevo observado no primeiro ponto de parada numa área assentada sobre litologias da Formação Santa Maria (Membro Alemoa).

1 Disponível para download em: <http://www.dpi.inpe.br/ spring/>.

${ }^{2}$ Disponível em: $<$ http://www. chapeco.sc.gov.br/secretarias/ secretaria-de-planejamento/ down loads.html>. Acesso em: 12 dez. 2011.

3 Disponível em: < http:// ciram.epagri.sc.gov.br/ mapoteca/>. Acesso em: 23 abr. 2012.

4 Disponível para download em: <http://www.google.com. br/earth>.

${ }^{5}$ Disponível em: $<$ http://www. dgi.inpe.br/CDSR/>. Acesso em: 5 fev. 2013.

Geografia Ensino \& Pesquisa, v. 17, n.3, p. 229-241, set./dez. 2013

Aula de campo em Geomorfologia: entre Santa Maria e São Martinho da Serra, RS

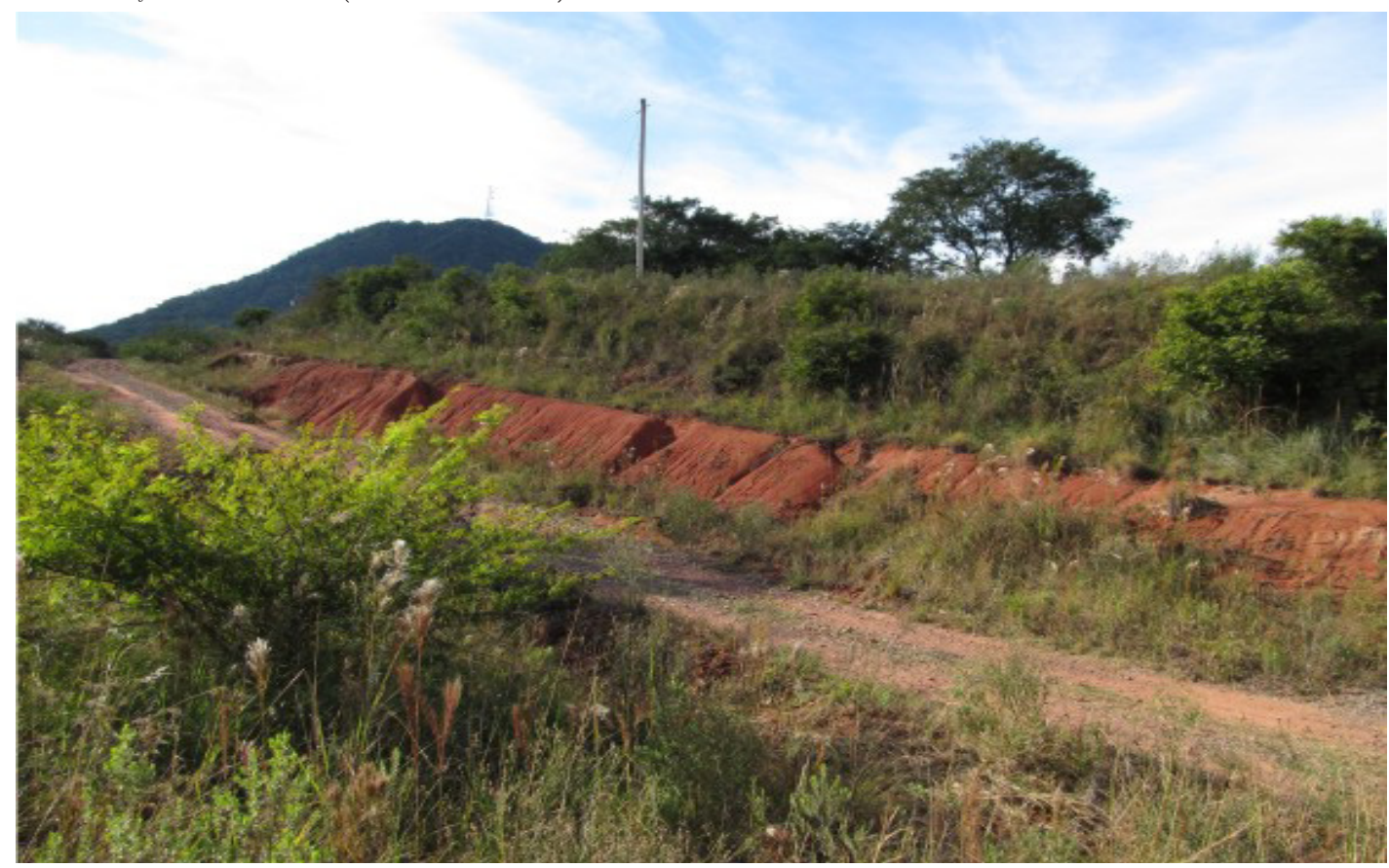

Fonte: arquivo pessoal dos autores.

Em alguns pontos ocorrem pequenos terraços fluviais e sedimentação quaternária, caracterizando-se por apresentar uma topografia suave e com modelado de acumulação. Essas áreas aluviais estão constituídas principalmente por sedimentos recentes (Quaternário) que foram removidos de superfícies topograficamente mais elevadas e depositados nas áreas mais planas das margens dos cursos fluviais mais importantes, sob o ponto de vista da atuação dos processos de acumulação. A Figura 3 ilustra essa abordagem. 
Figura 3 - Conformação do relevo observado no primeiro ponto de parada numa área assentada sobre sedimentação quaternária, caracterizando-se por apresentar uma topografia suave e com modelado de acumulação.

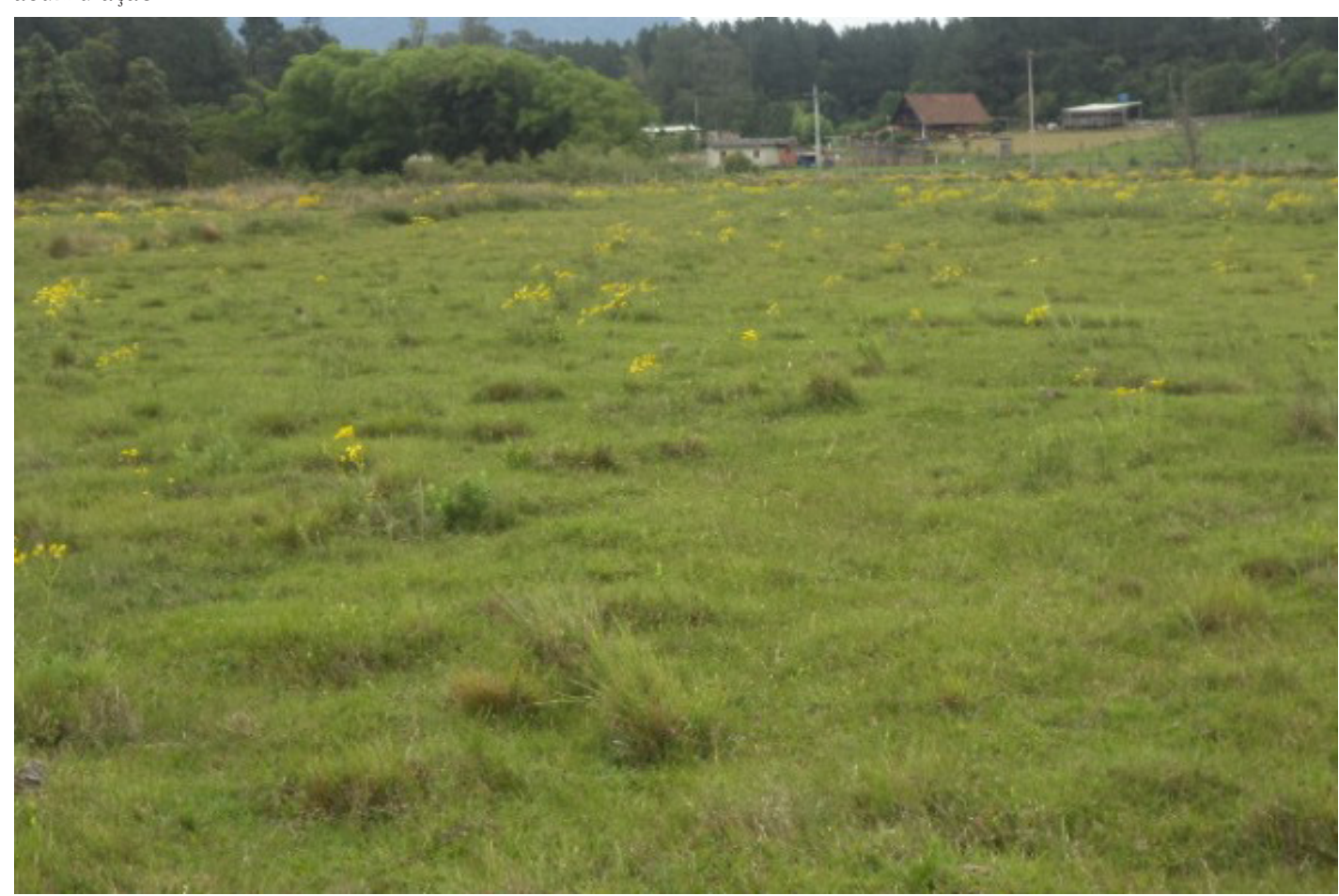

Fonte: arquivo pessoal dos autores.

Em relação a outras características do ambiente regional, no que se refere a hidrografia, destacou-se que a área pertence ao sistema da bacia do rio Vacacaí-Mirim. Esse apresenta um padrão de drenagem que, na classificação de Christofoletti (1980) enquadra-se no tipo subdentrítico (apresenta controle estrutural no curso principal). Em alguns casos o controle estrutural caracteriza padrão sub-paralelo na drenagem. Está representada por canais de primeira e segunda ordem. Estes canais são responsáveis tanto pelo modelado de acumulação, quanto pelo modelado aplanamento e dissecação dos interflúvios e entalhamento dos talvegues. Também se destacou que a área sofreu significativas alterações na cobertura original da vegetação. Apresenta aspectos da biota regional inseridas, conforme Vieira (1984) no domínio dos Campos com Capões e Matas Galerias. Em relação ao clima, com base na classificação de Köppen, apud Ayoade (1986) enquadrase como sendo mesotérmico brando Cfa. As precipitações são regulares durante todo o ano, não apresentando estação seca.

\section{Ponto de parada 2}

Nesse ponto foi observado o aspecto geral do comportamento do relevo e, ao se observar morfologia da paisagem, desde a Depressão Periférica Sul-riograndense num sentido de sul para norte tem-se: onde ocorre a Formação Santa Maria-membro Alemoa, é possível observar o relevo com uma topografia suave. Num outro plano, sobre a Formação Caturrita, a topografia se apresenta ondulada a forte ondulada. Num terceiro plano de visada, em área de ocorrência da Formação Botucatu, o relevo se apresenta com topografia forte ondulada e com a presença de patamares. Num último plano de visão, sobre áreas de ocorrência da Formação Serra Geral, se observa o relevo com uma topografia montanhosa com presença de patamares e ressaltos topográficos escalonados formando escarpas. A Figura 4 ilustra o aspecto geral da paisagem observada desde o ponto onde ocorre a presença de um patamar sobre a Formação Botucatu, numa visão da Depressão Periférica Sul-riograndense num sentido de norte para sul e, a Figura 5, mostra um ponto onde ocorre o aspecto escalonado do relevo na área da Formação Serra Geral. Em relação a hidrografia, a área

Geografia Ensino \& Pesquisa, v. 17, n.3, p. 229-241, set./dez. 2013

Werlang, M. K.; Pontes, R. C.; Sarmento, F. L. 
está dissecada pelos cursos d'água pertencentes ao sistema da bacia do rio Vacacaí-Mirim que drena para o sul/sudeste e do rio Ibicuí-Mirim com a rede de drenagem dissecando os interflúvios para o setor sul/sudoeste da área observada. Quanto à vegetação, apresenta aspectos da biota regional com espécies tanto da Floresta Estacional Decidual (ecossistema do Bioma Mata Atlântica), como dos Campos com Capões (ecossistema do Bioma Pampa).

Figura 4 - Conformação geral da paisagem observada em um local onde ocorre a presença de um patamar formado sobre a Formação Botucatu, numa visão desde a o Rebordo do Planalto em direção a Depressão Periférica Sul-riograndense num sentido de visada norte-sul.

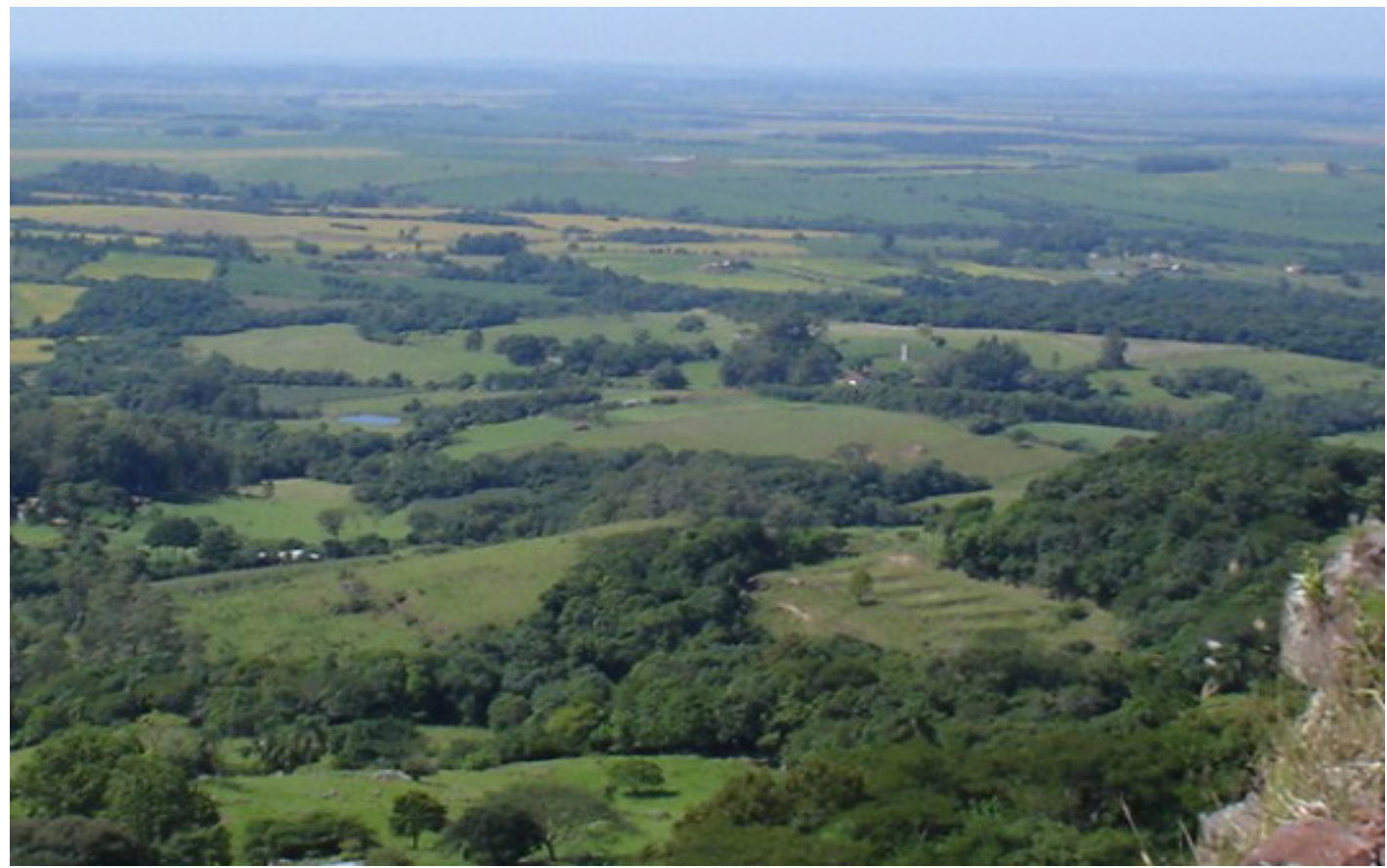

Fonte: arquivo pessoal dos autores.

Figura 5 - Conformação da paisagem observada em um ponto onde ocorre o aspecto escalonado do relevo na área de ocorrência da Formação Serra Geral

Geografia Ensino \& Pesquisa, v. 17, n.3, p. 229-241, set./dez. 2013

Aula de campo em Geomorfologia: entre Santa Maria e São Martinho da Serra, RS

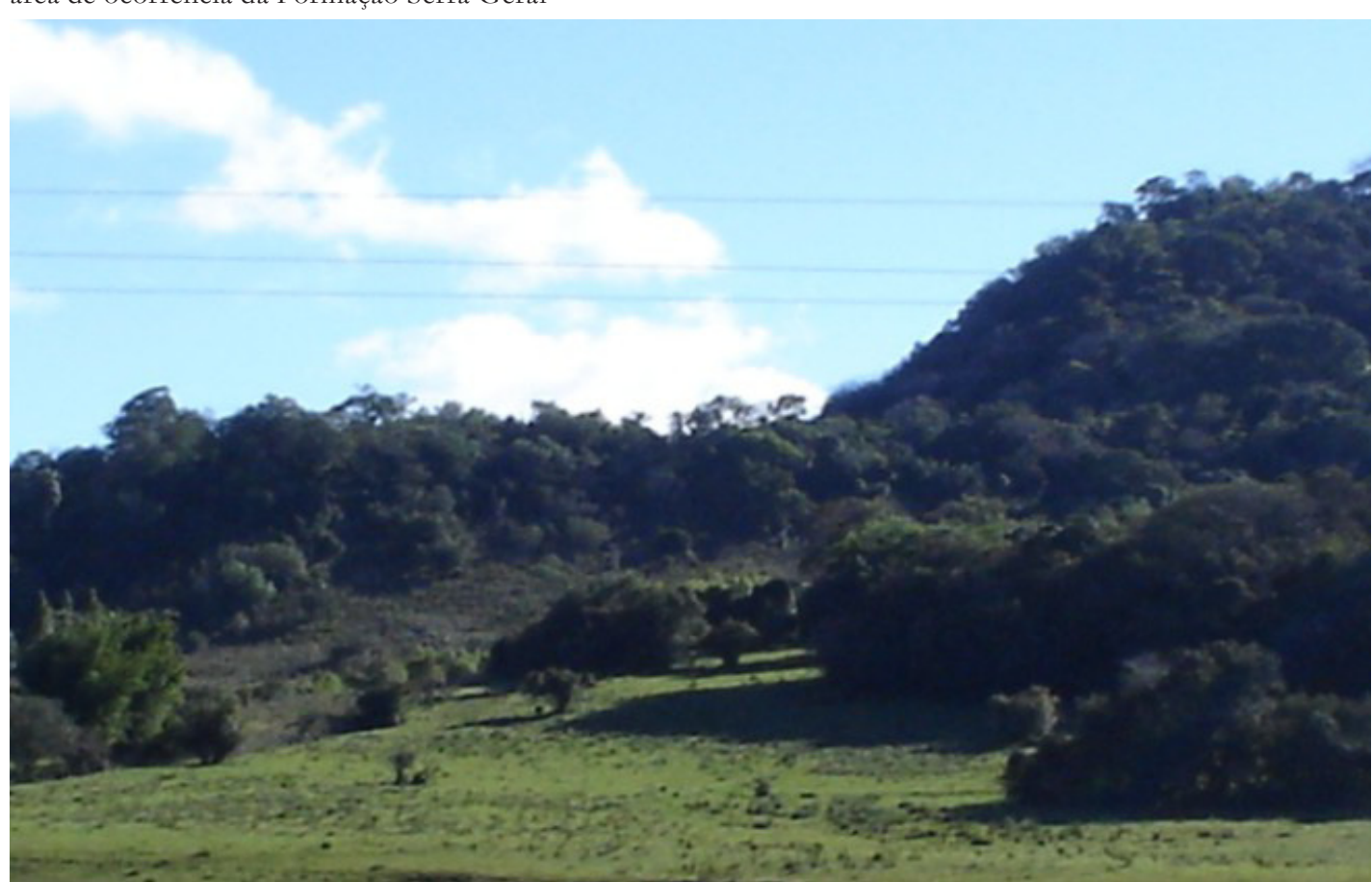

Fonte: arquivo pessoal dos autores. 
Em relação ao manto pedológico ocorrem argissolos que estão presentes nos setores bem drenados dos interflúvios. Também estão presentes planossolos, gleissolos, além de plintosolos em setores mal drenados dos interflúvios. Cambissolos e neossololos litólicos puderam ser observados nas áreas mais declivosas dos interflúvos sobre áreas de ocorrência da Formação Serra Geral. A Figura 6 ilustra o aspecto de um plintossolo.

Figura 6 - Aspecto de um corte de estrada deixando à mostra o perfil do solo onde ocorre um plintossolo.

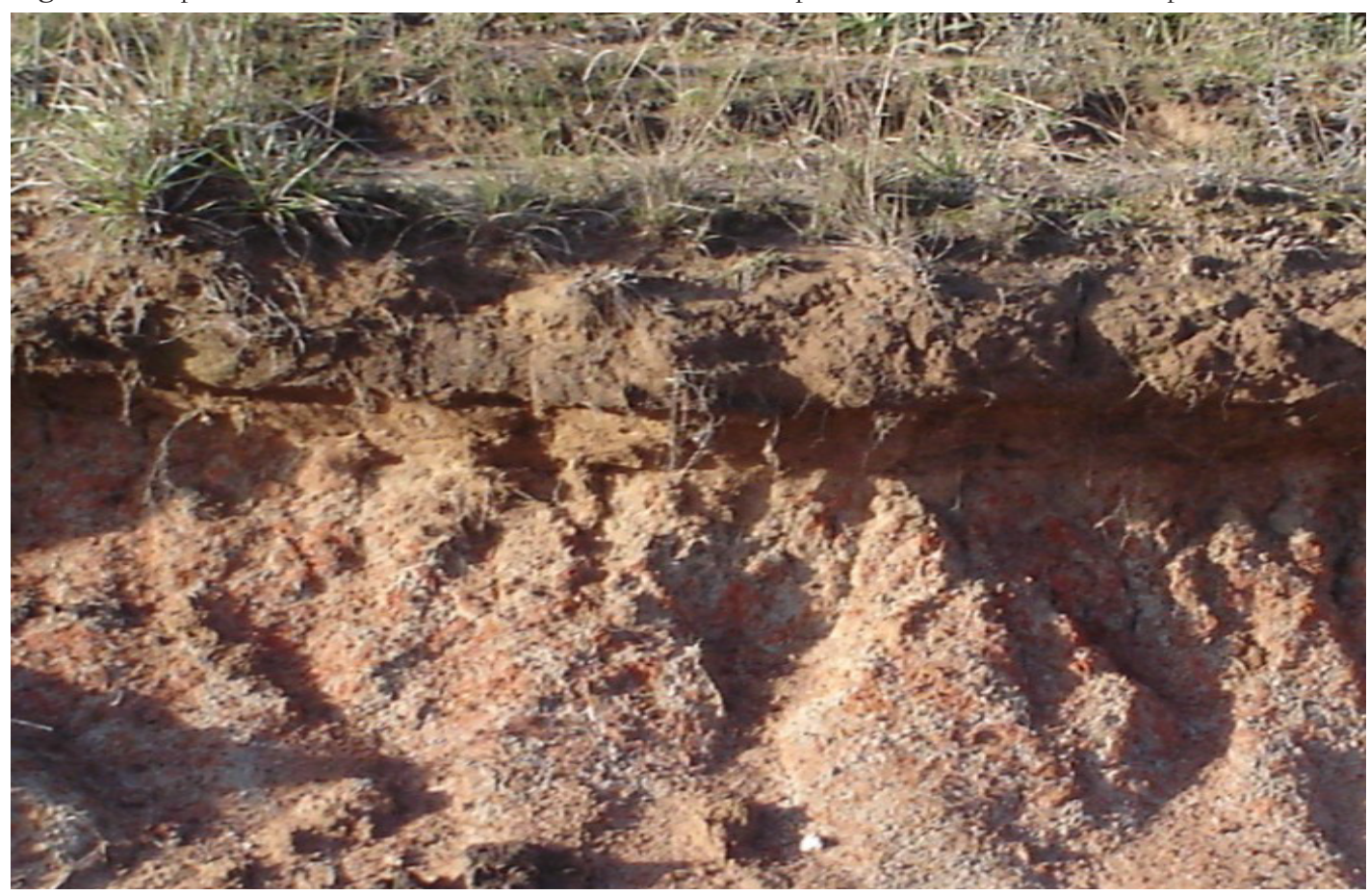

Fonte: arquivo pessoal dos autores.

Em algumas vertentes observadas, a presença do horizonte $\mathrm{E}$ e/ou $\mathrm{Bt}$ no perfil do solo, permitiu inferir que alguns pequenos ressaltos topográficos verificados estão relacionados à dinâmica erosiva promovida pela característica destes horizontes. Nesse sentido, pode ser considerado que algumas vertentes apresentam uma dinâmica de denudação relacionada aos processos de infiltração/exfiltração da água motivadas pela presença destes horizontes ao longo da toposseqüência dos interflúvios.

\section{Ponto de parada 3}

O terceiro ponto de parada foi realizado, no trajeto Santa Maria-São Martinho da Serra, logo após (aproximadamente $1 \mathrm{~km}$ ) a ponte sobre o rio Ibicuí-Mirim. Nesse ponto de parada foi observado o aspecto geral da conformação do modelado do relevo. Para isso foram consideradas as observações realizadas nos outros pontos já observados ao longo do trajeto. Nesse ponto de parada foi visualizado o contato litológico entre as Formações Caturrita e Botucatu. A Figura 7 ilustra o contato litológico entre as Formações Caturrita e Botucatu. Seguindo logo adiante, ainda neste ponto de parada, também foi possível visualizar o contato entre as Formações Botucatu e Serra Geral, configurando a presença do arenito intertrapp. A Figura 8 ilustra um desses contatos. Também, nesse ponto de parada, foram observados processos de coluviação e deposição fluvial ao longo dos interflúvios e várzea do rio. Em alguns setores das vertentes com modelado de dissecação médio e forte, se observaram formas de erosão a partir do escoamento entressulcos e a formação de canais incisivos como ravinas e voçorocas. A Figura 9 ilustra um desses pontos. Ainda foram visualizados em alguns setores de vertentes, sedimentos inconsolidados como resultado de depósitos de tálus e/ou colúvios conforme ilustra a Figura 10.

Geografia Ensino \& Pesquisa, v. 17, n.3, p. 229-241, set./dez. 2013

Werlang, M. K.; Pontes, R. C.; Sarmento, F. L.

ISSN 2236-4994 | 235 
Figura 7 - Contato litológico entre as Formações Caturrita e Botucatu.

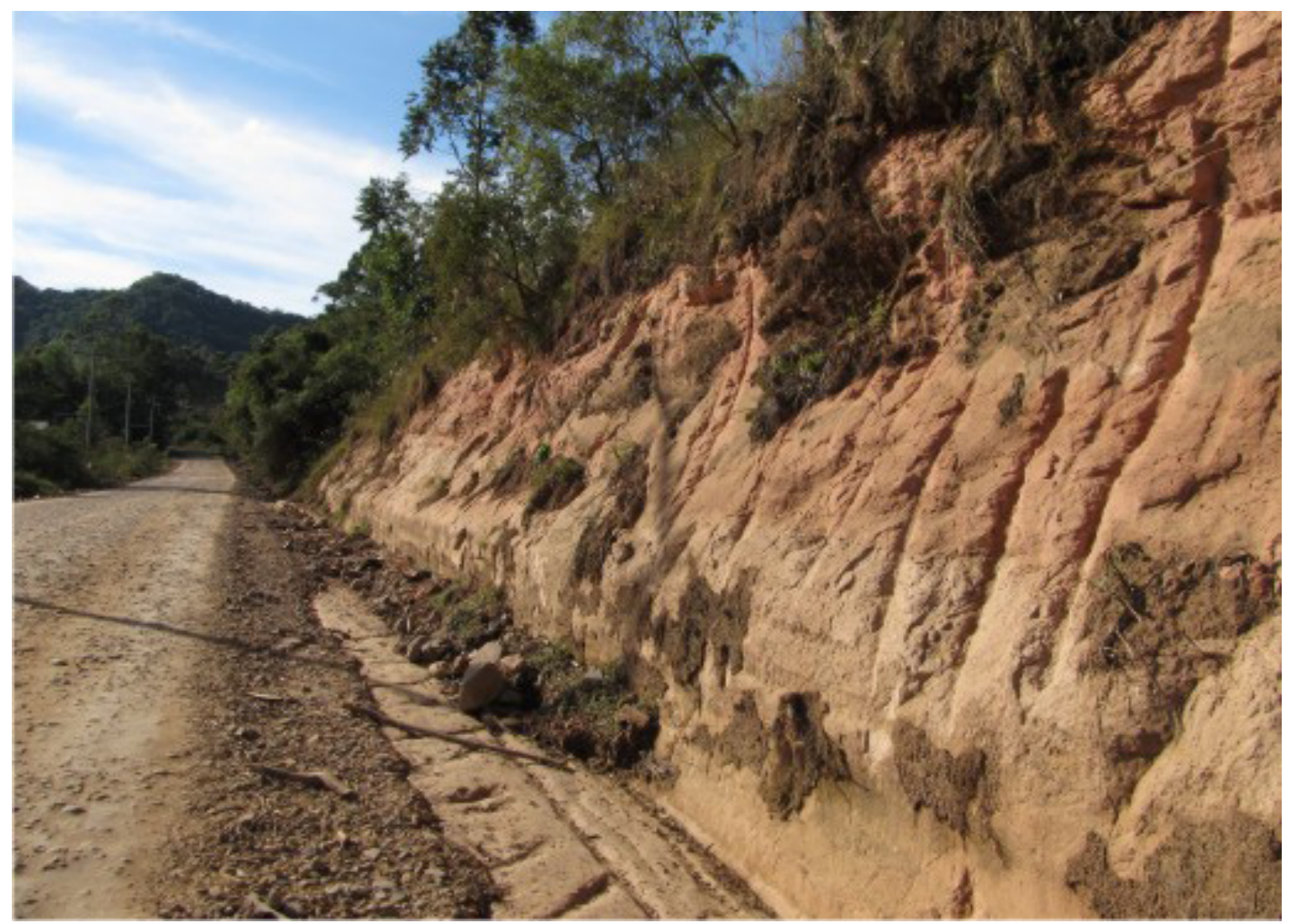

Fonte: arquivo pessoal dos autores.

Figura 8 - Contato litológico entre as Formações Botucatu e Serra Geral.

Geografia Ensino \& Pesquisa, v. 17, n.3, p. $229-241$, set./dez. 2013

Aula de campo em Geomorfologia: entre Santa Maria e São Martinho da Serra, RS

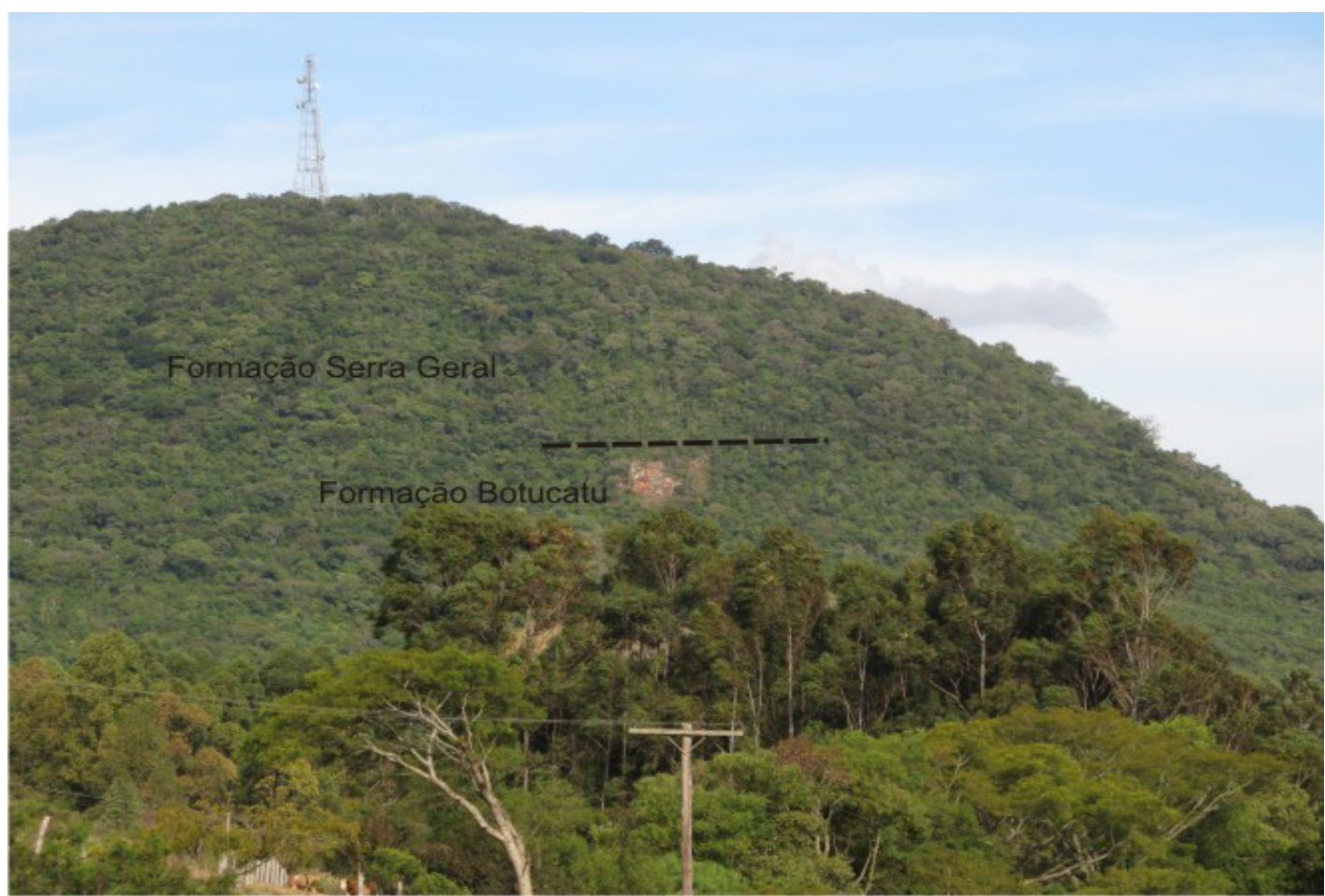

Fonte: arquivo pessoal dos autores. 
Figura 9 - Ponto onde se observa processo de erosão hídrica a partir do escoamento entressulcos e a formação de canais incisivos.

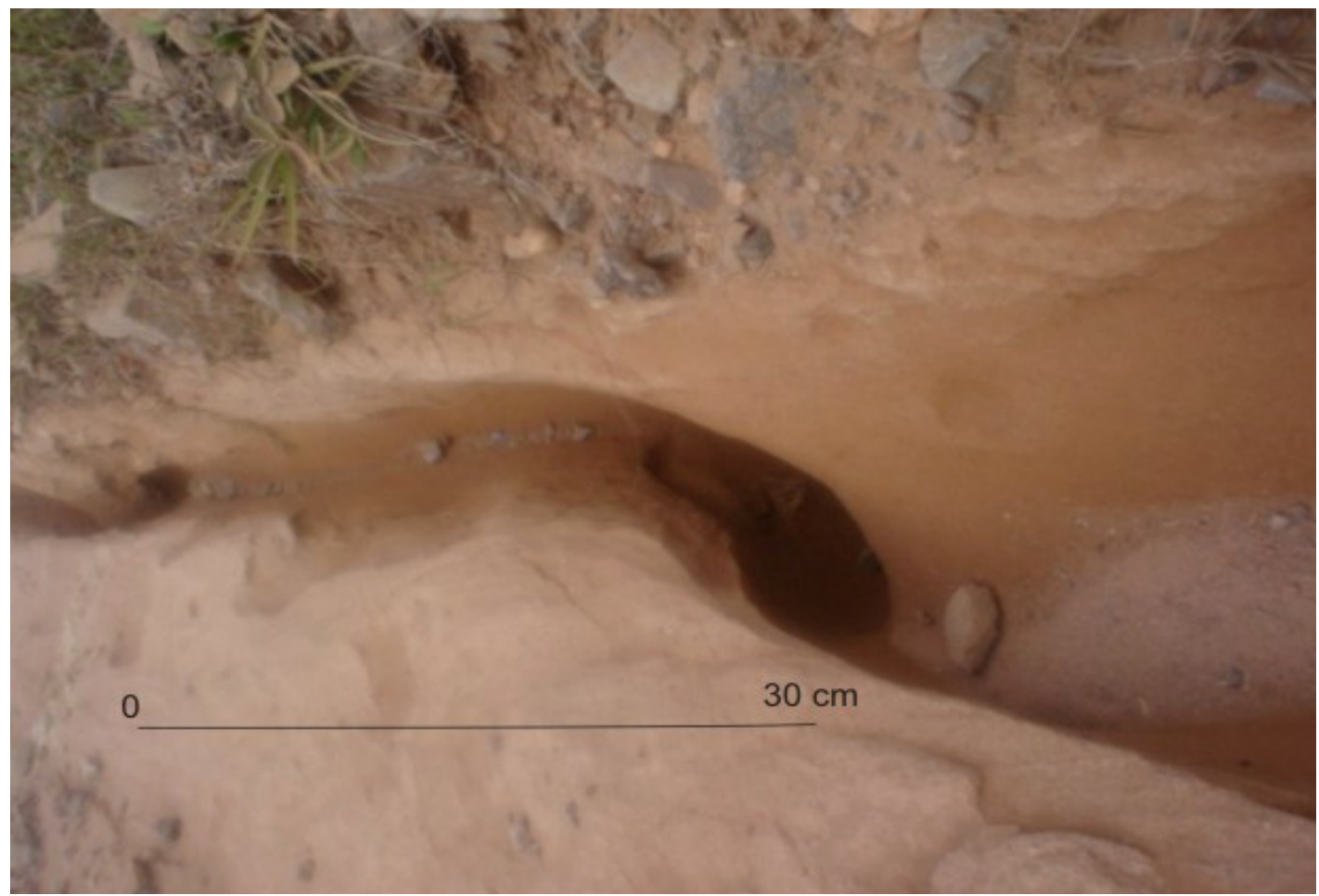

Fonte: arquivo pessoal dos autores.

Figura 10 - Vertente com modelado de dissecação médio a forte onde se observam sedimentos inconsolidados como resultado de depósitos de tálus.

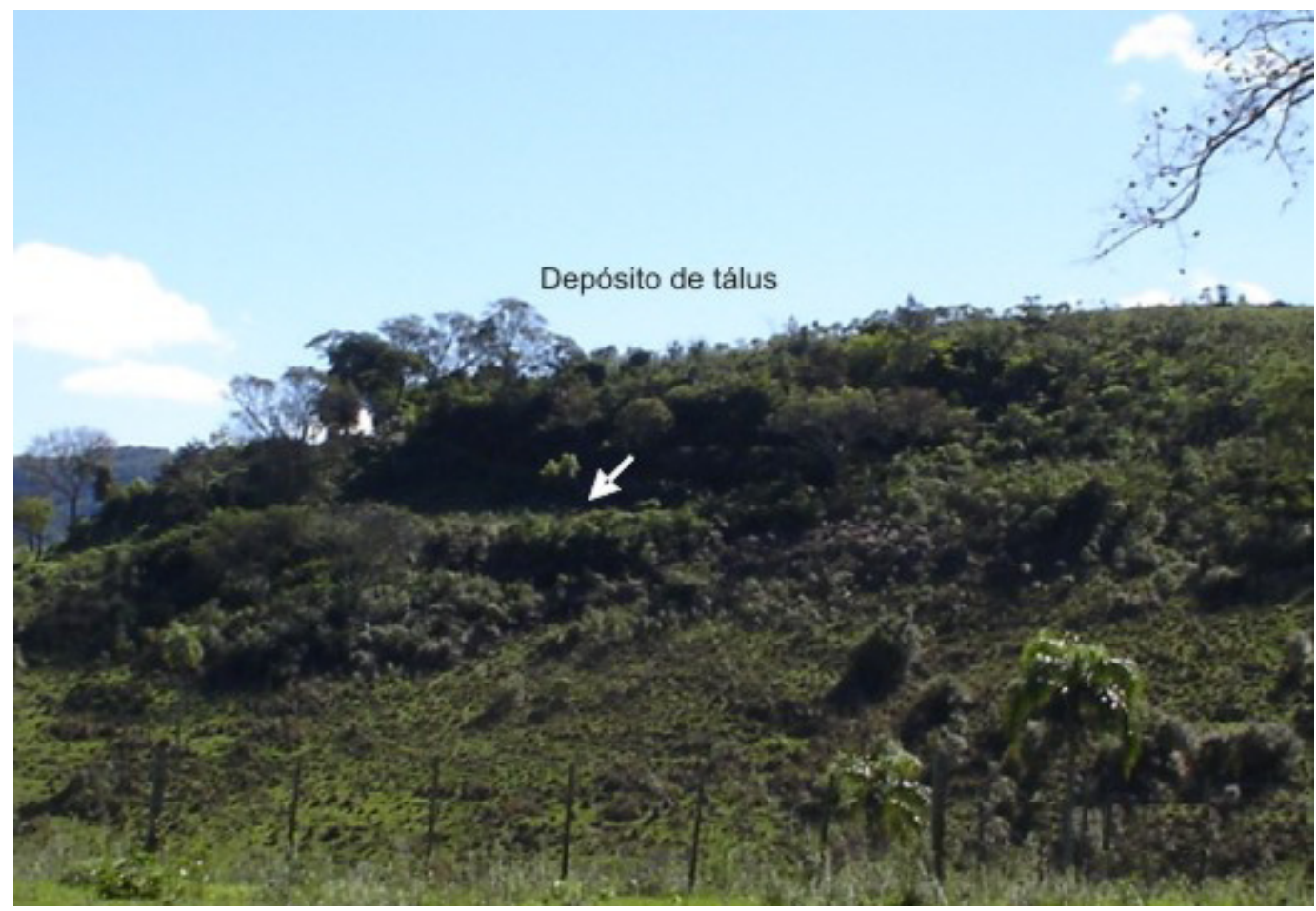

Fonte: arquivo pessoal dos autores.
Geografia Ensino \& Pesquisa, v. 17, n.3, p. 229-241, set./dez. 2013

Werlang, M. K.; Pontes, R. C.; Sarmento, F. L. 


\section{Ponto de parada 4}

Esse ponto de parada constituiu-se na observação de formas de relevo cuja evolução está relacionada a processos que atuaram sobre litologias da Formação Serra Geral (formada por rochas vulcânicas efusivas básicas e ácidas) do topo e rebordo dos Planaltos e Chapadas da Bacia Sedimentar do Paraná. Desde o topo, observando-se para o sul e sudoeste do município de São Martinho da Serra, RS visualiza-se o rebordo onde ocorrem saliências e reentrâncias resultantes do festonamento desse rebordo erosivo. A Figura 11 ilustra a ocorrência de um morro testemunhando o recuo do rebordo erosivo do Planalto e, a Figura 12, ilustra um aspecto do festão do rebordo.

Figura 11 - Morro testemunho ilustrando o recuo do rebordo dos Planaltos e Chapadas da Bacia Sedimentar do Paraná no sul o município de São Martinho da Serra, RS.

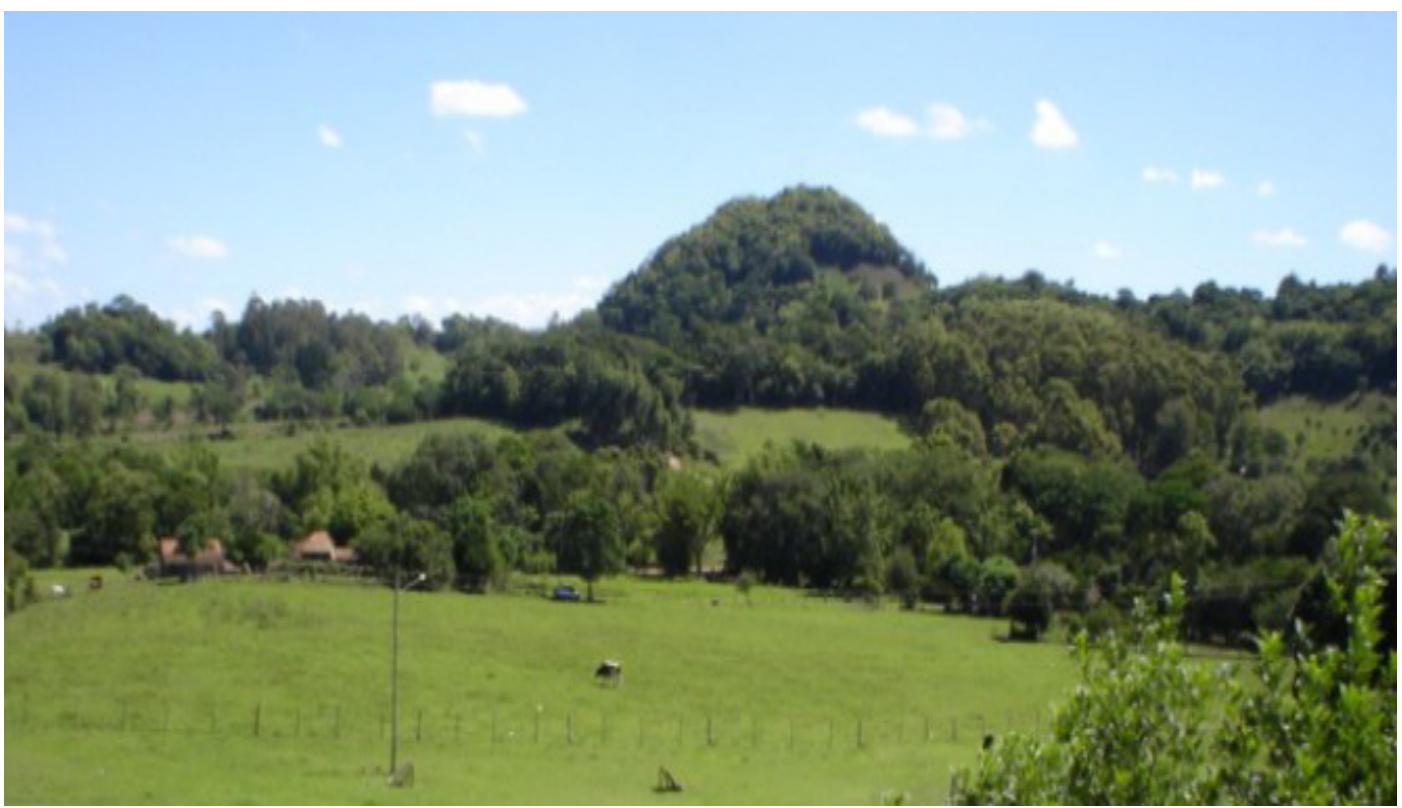

Fonte: arquivo pessoal dos autores.

Figura 12 - Aspecto do festonamento do rebordo ilustrando o recuo do rebordo dos Planaltos e Chapadas da Bacia Sedimentar do Paraná no sul o município de São Martinho da Serra, RS.

Geografia Ensino \& Pesquisa, v. 17, n.3, p. $229-241$, set./dez. 2013

Aula de campo em Geomorfologia: entre Santa Maria e São Martinho da Serra, RS

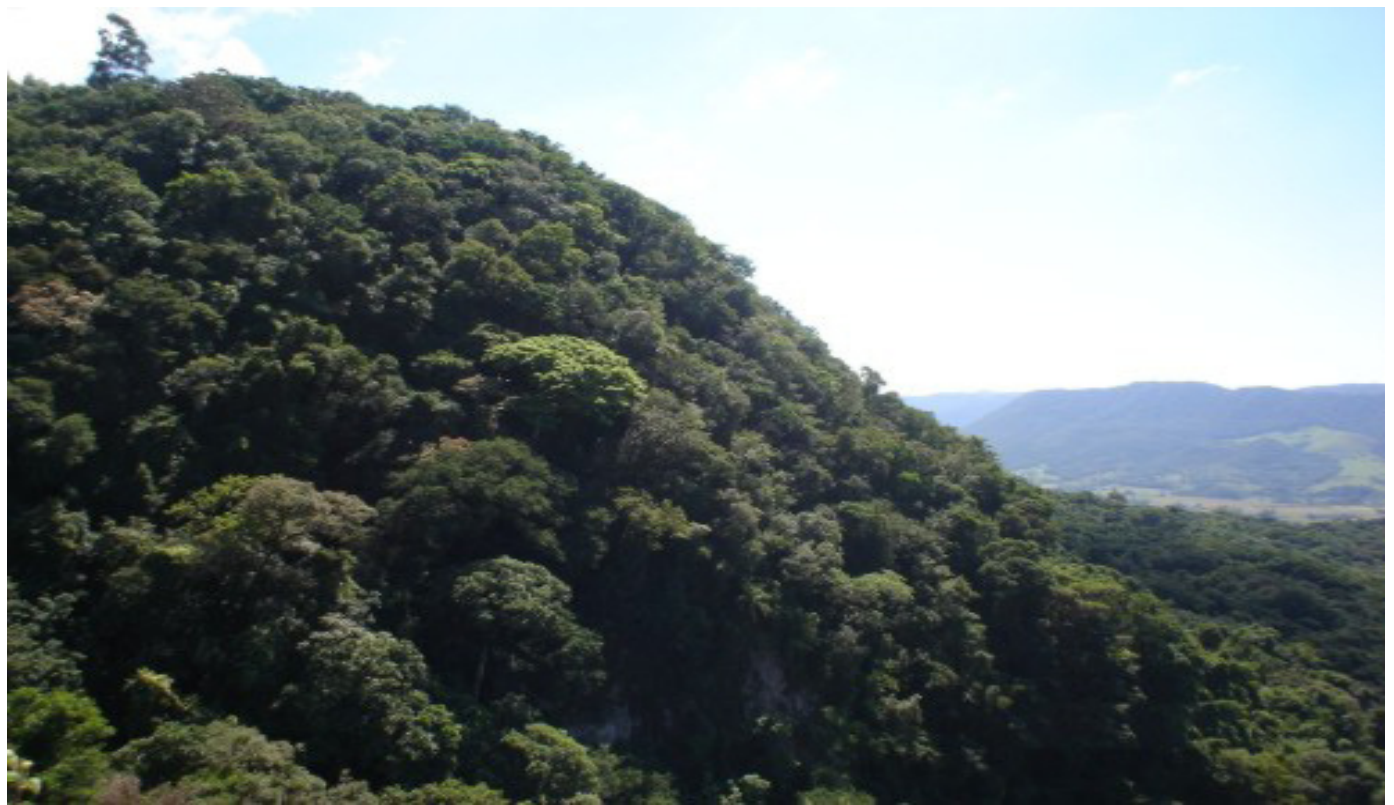

Fonte: arquivo pessoal dos autores. 
Também nesse ponto de parada, foi observada a presença de uma cornija mantida por uma camada mantenedora cuja litologia predominante está composta por rochas vulcânicas ácidas da Formação Serra Geral. A Figura 13 ilustra o aspecto dessa litologia e, a Figura 14, mostra um paredão abrupto formado pela presença de uma cornija. A Figura 15 mostra o aspecto do relevo do topo do planalto, com uma topografia suave ondulada.

Figura 13 - Aspecto da litologia da Formação Serra Geral (formada por rochas vulcânicas efusivas básicas e ácidas) do topo e rebordo dos Planaltos e Chapadas da Bacia Sedimentar do Paraná no sul do município de São Martinho da Serra, RS.

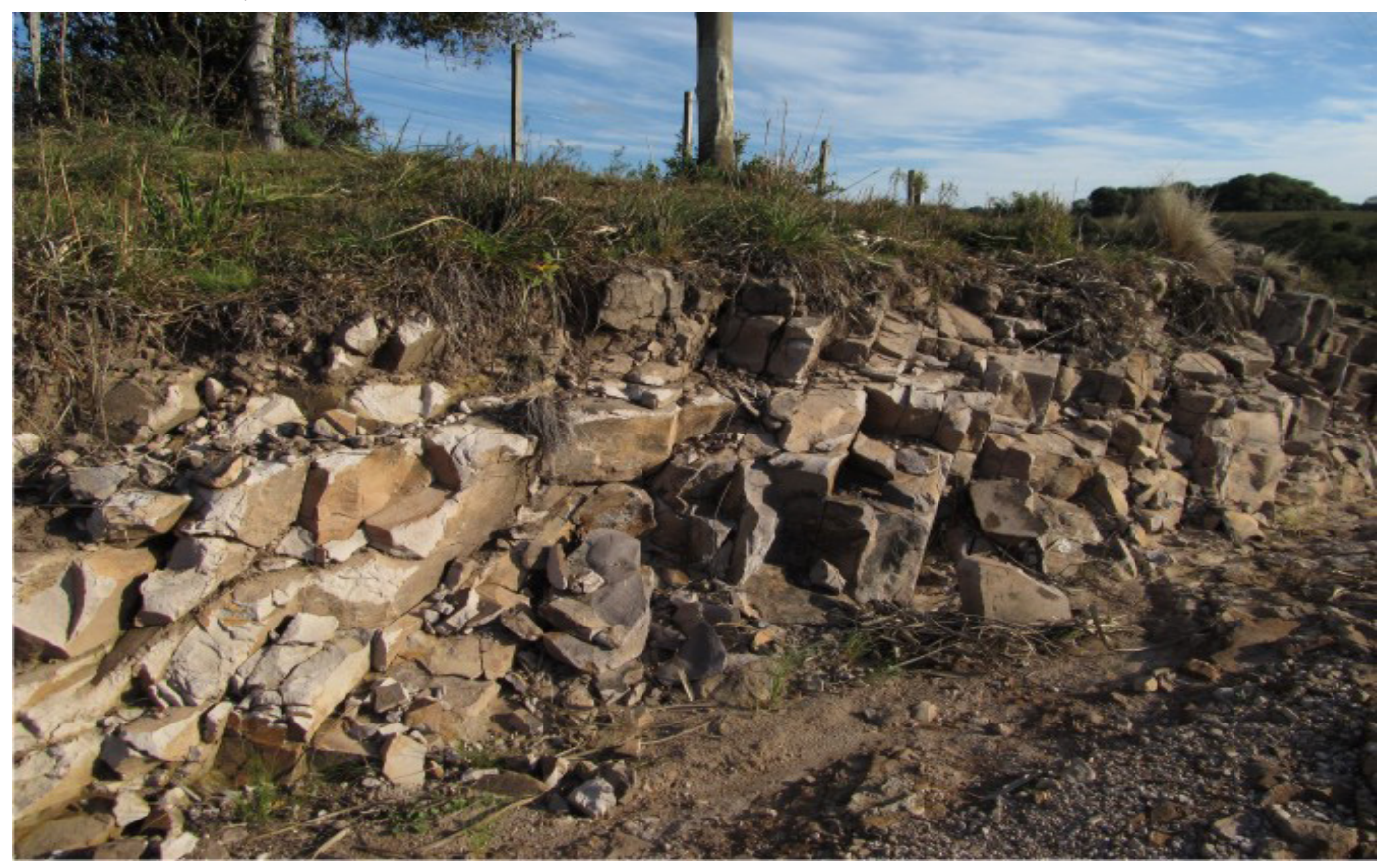

Fonte: arquivo pessoal dos autores.

Figura 14 - Aspecto do festonamento do rebordo ilustrando a presença de uma cornija mantida por uma camada mantenedora cuja litologia predominante está composta por rochas vulcânicas ácidas da Formação Serra Geral no rebordo dos Planaltos e Chapadas da Bacia Sedimentar do Paraná no sul do município de São Martinho da Serra, RS.

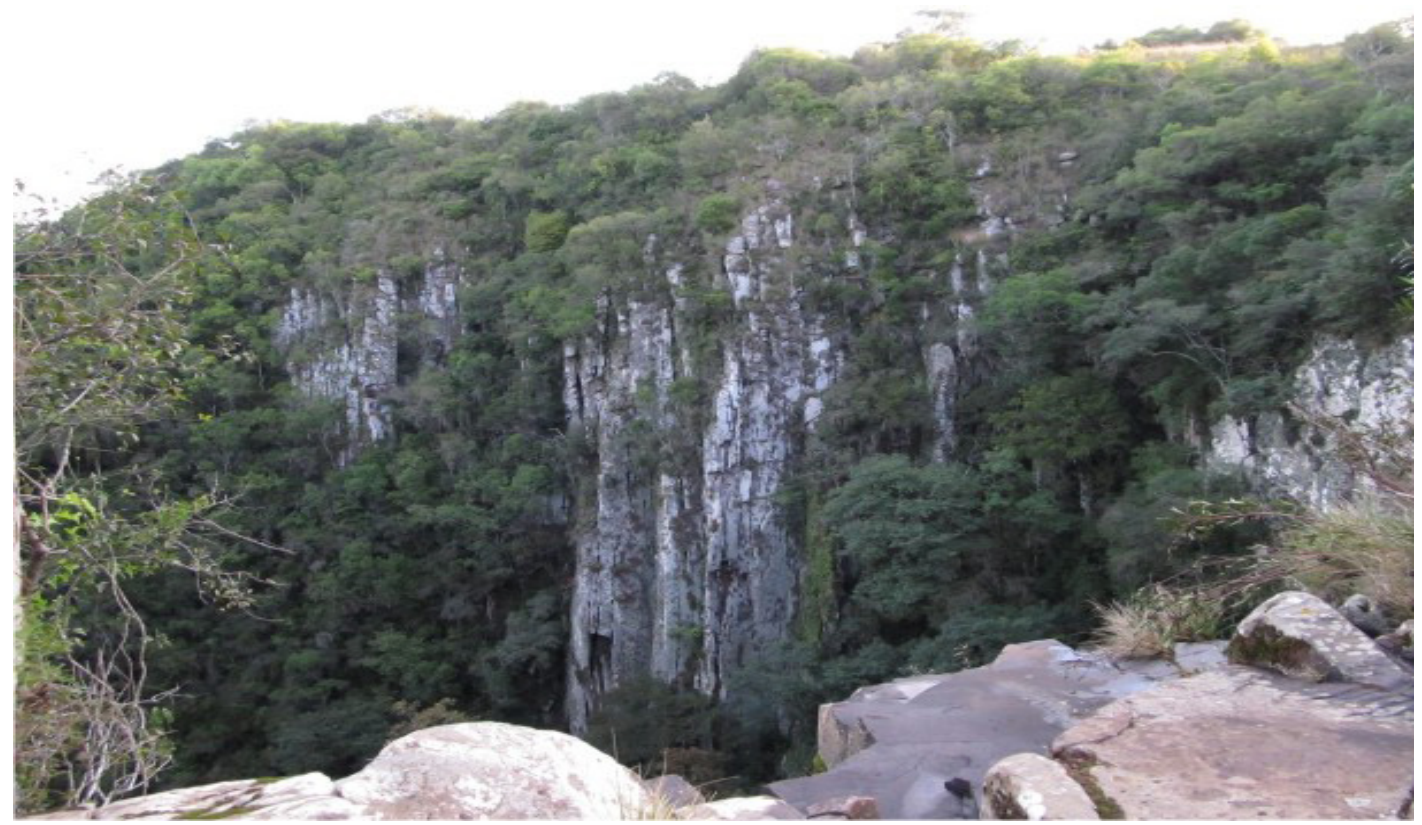

Fonte: arquivo pessoal dos autores.
Geografia Ensino \& Pesquisa, v. 17, n.3, p. 229-241, set./dez. 2013

Werlang, M. K.; Pontes, R. C.; Sarmento, F. L. 
Figura 15 - Aspecto do relevo com uma topografia suave ondulada ilustrando a paisagem do topo dos Planaltos e Chapadas da Bacia Sedimentar do Paraná no sul do município de São Martinho da Serra, RS.

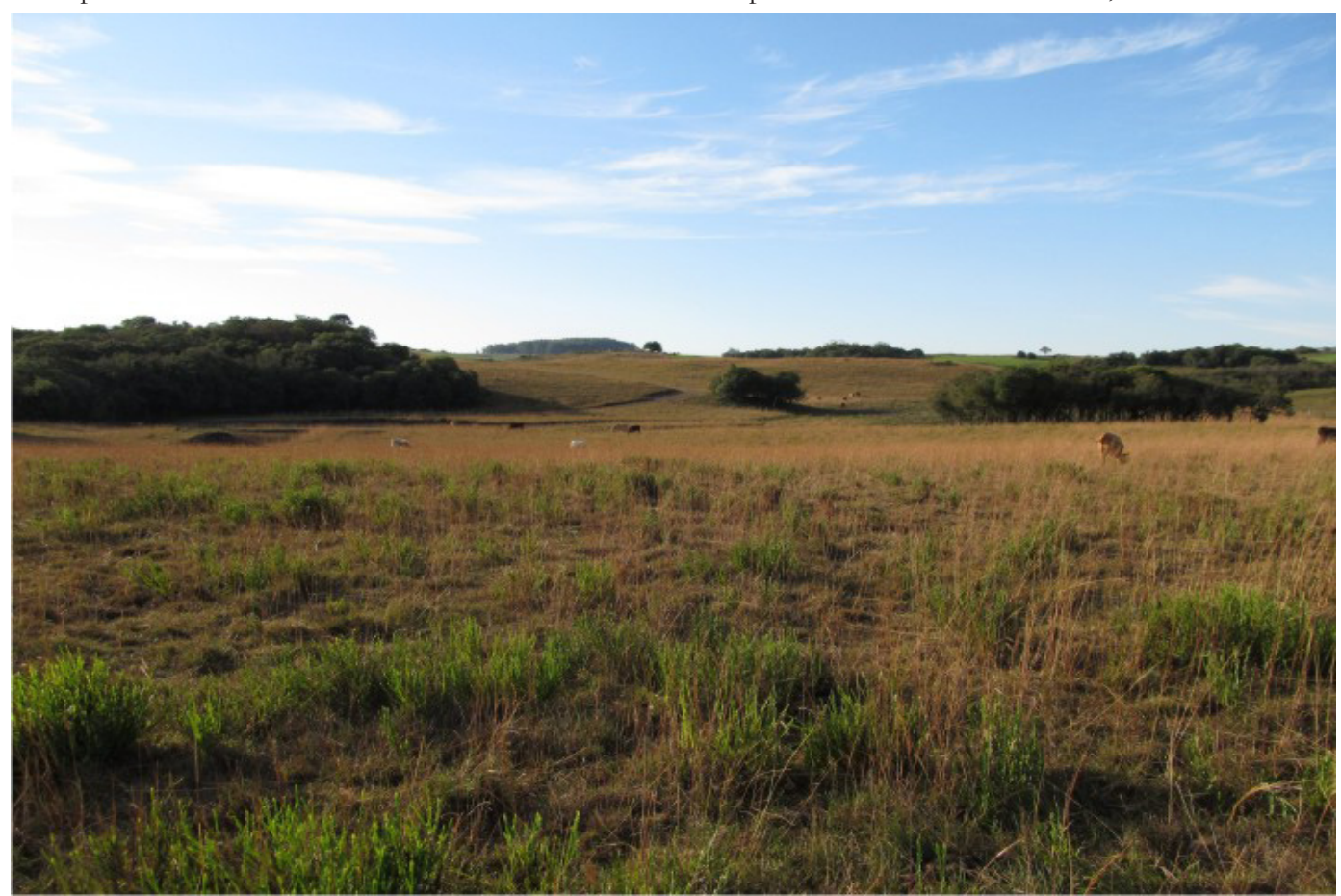

Fonte: arquivo pessoal dos autores.

Como visto, nesse ponto de parada, foram observados aspectos relativos ao rebordo erosivo e o controle litológico/estrutural presente desde o topo até o rebordo do Planalto. Se observado, desde o topo numa toposseqüência sul/sudoeste, verifica-se a presença de uma topografia montanhosa, com patamares e ressaltos topográficos escalonados e, se observada uma toposseqüência norte, visualiza-se relevo com uma topografia suave ondulada caracterizando o relevo do município de São Martinho da Serra, RS.

\section{Consideração final}

A partir dos quatro pontos de paradas foi possível descrever algumas características geomorfológicas de lugares no percurso desenvolvido na aula de campo desde Santa Maria, RS até São Martinho da Serra, RS. Ao se observar o comportamento do relevo face ao controle estrutural, litológico e a dinâmica erosiva que atua nos processos de modelado do relevo, foram reconhecidos relevos desenvolvidos sobre sedimentos atuais e terraços fluviais, bem como relevos desenvolvidos sobre litologias da Formação Santa Maria (Membro Alemoa), Caturrita, Botucatu e Serra Geral. Também foram reconhecidos contatos litológicos entre as Formações Caturrita e Botucatu e, entre as Formações Botucatu e Serra Geral. Conclui-se que é possível trabalhar, a partir da observação in loco, a relação dos processos morfogenéticos considerando-se o controle estrutural/litológico e a dinâmica erosiva na conformação do relevo nesse trajeto desde a Depressão Periférica Sul-riograndense (Santa Maria, RS) até o topo dos Planaltos e Chapadas da Bacia Sedimentar do Paraná (São Martinho da Serra, RS). Também se conclui adequada a metodologia para análise do relevo considerando abordagens descritivas a partir de modelos estático e dinâmico, para o entendimento da conformação e evolução do relevo nesta região.

Geografia Ensino \& Pesquisa, v. 17, n.3, p. 229-241, set./dez. 2013

Aula de campo em Geomorfologia: entre Santa Maria e São Martinho da Serra, RS

\section{Referências}

ALVES, R. Filosofia da Ciência: introdução ao jogo e suas regras. São Paulo: Brasiliense, 1981. cap. 7, p. 116-118.

AYOADE, J. Introdução a climatologia dos trópicos. São Paulo: Difel, 1986. 
BORTOLUZZI, C.A. Contribuição à Geologia da Região de Santa Maria, Rio Grande do Sul, Brasil. Pesquisas, Porto Alegre, v. 4, n. 1, p.7-86, 1974.

CHRISTOFOLETTI, A. Geomorfologia. São Paulo: Edgard Blücher, 1980.

GIL, A.C. Métodos e técnicas de pesquisa social. São Paulo: Atlas, 1999. Disponível em: http://pt.scribd.com/doc/2367267/DA-SILVA-MENEZES-2001-Metodologia-da-pesquisae-elaboracao-de-dissertacao Acesso em: 08 de julho de 2011.

INSTITUTO BRASILEIRO DE GEOGRAFIA E ESTATÍSTICA - IBGE. CIDADES: Rio Grande do Sul. Disponível em http://www.ibge.gov.br/cidadesat Acesso em: 23 out.2010.

MACIEL FILHO, C.L.; SARTORI, P.L.P; VEIGA, P.; GASPARETTO, N.V.L; Mapa Geológico da Folha de Camobi. Santa Maria-RS: Imprensa Universitária, FINEP-UFSM, 1990.

ROSS, J. L. Geografia do Brasil. São Paulo: Edusp, 1996.

VEIGA, P. Estudo dos arenitos "intertrapps" da Formação Serra Geral na região de Santa Maria: Programa de Pós-Graduação em Geociências - Dissertação de Mestrado, Universidade Federal do Rio Grande do Sul, Porto Alegre,1973.

VIEIRA, E. Falcão. Rio Grande do Sul. Geografia física e vegetação. Porto Alegre: Sagra, 1984.

WERLANG, M. K. Configuração da rede de drenagem e modelado do relevo: Conformação da paisagem na zona de transição da Bacia do Paraná na Depressão Central do Rio Grande do Sul. Santa Maria-RS: Programa de Pós-Graduação em Ciência do Solo - Tese de Doutorado, Universidade Federal de Santa Maria, 2004.

\section{Correspondência:}

Mauro Kumpfer Werlang - Universidade Federal de Santa Maria (UFSM), Departamento de Geociências, Curso de Geografia. Avenida Roraima, Prédio 17, Cidade Universitária, Bairro Camobi, Santa Maria - RS, CEP 97105-000.

E-mail: mkwerlang@smail.ufsm.br

Recebido em 29 de abril de 2013.

Revisado pelo autor em 23 de dezembro de 2013.

Aceito para publicação em 23 de dezembro de 2013.

Geografia Ensino \& Pesquisa, v. 17, n.3, p. 229-241, set./dez. 2013

Werlang, M. K.; Pontes, R. C.; Sarmento, F. L. 